\title{
KEPARIWISATAAN ALAM MERESPON TANTANGAN PERUBAHAN IKLIM Studi Kasus di Taman Nasional Tanjung Putting
}

\author{
Johan Setiawan \\ Taman Nasional Tanjung Putting - Kalimantan Tengah
}

\begin{abstract}
Climate may affect the quality and type of tourism activities that developed within a region. There are some natural tourism resources which is very vulnerable toward direct and indirect impacts of the climate change threats. Increased extremely temperatures and also the changes in length of winter or summer may affect visitors length of stay. On the other hand, tourism may contribute to global warming through gas emissions from transportation, accommodation and other related tourism activities. In 2005 UNWTO predict if the tourism business is run as 'business-as-usual' scenario, there is no any response or adaptation program, that predicted in 2035 the emissions produced from tourism sector will increase $161 \%$ higher than today. Considering these facts, UNWTO invites overall stakeholders of individual to the State level responding to the climate change phenomena by implementing adaptation program in order to reduce greenhouse gas emissions and preventing global warming threats.

This study aims to understand the characteristics of visitor typology and their points of view toward the climate change phenomena. It is also purposed to explore and assess adaptation program that can be developed in Tanjung Puting National Park (TPNP) based on their perspective. The results of this study are as follows: (1). the tourism market of TPNP has a feature of 'eco-tourist' with a high awareness and concern towards environmental issues, including the threat of climate change phenomena. Visitors of TPNP have a high ethical manner for nature and local culture. Generally, the visitors also have a higher education and income, which is very potential to engage them into an environmental conservation, (2). The visitors of TPNP realize that climate change is a serious challenge and need a concrete action. Some adaptation program desired by the visitors are fund raising program for Orangutan conservation and its habitat. The visitors are likely willing to give a donation Rp.172,000.00/visitor. Such concept of the donation is a mechanism of offset emissions generated due their visits by providing funds for conservation efforts. The visitors encourage managers of the destination for improvisation and technology investment in the boat (kelotok) machine which as the machine is efficient and less noisy. The visitors also encourage TPNP authority to limit the number of visitors in order to protect the tourism resource of TPNP and maintain the quality of visits; (3). The visitors were unwilling joined with other guests into any public boat of a larger capacity, in order to keep fuel efficiency and GHG mitigation. Merging the visitors traveling with another group instead reducing quality of their trip in Tanjung Puting National Park (TPNP). The visitors are also unwilling to engage in any plantation activities in destination during their visit.
\end{abstract}

\section{Keywords:}

Climate change, ecotourism, response of adaptation, conservation, donation, GHG mitigation. 


\section{INTISARI}

Iklim dapat mempengaruhi kualitas dan jenis kegiatan wisata yang dikembangkan dalam suatu wilayah. Ada beberapa sumber daya wisata alam yang sangat rentan terhadap dampak langsung dan tidak langsung dari ancaman perubahan iklim. Peningkatan suhu dan juga perubahan musim dingin atau musim panas yang sangat panjang dapat mempengaruhi lama tinggal pengunjung. Di sisi lain, pariwisata berkontribusi pada pemanasan global melalui emisi gas dari transportasi, akomodasi dan kegiatan pariwisata. Pada tahun 2005 UNWTO memprediksi jika bisnis pariwisata dijalankan sebagai skenario 'bisnis biasa', tidak ada program adaptasi maka diperkirakan pada 2035 emisi yang dihasilkan dari sektor pariwisata akan meningkat 161\% lebih tinggi dari sekarang. Mengingat fakta ini, UNWTO mengundang seluruh stakeholder menanggapi fenomena perubahan iklim dengan menerapkan program adaptasi untuk mengurangi emisi gas rumah kaca dan mencegah ancaman pemanasan global.

Penelitian ini bertujuan untuk memahami karakteristik dan tipologi pengunjung terhadap fenomena perubahan iklim. Penelitian ini juga bertujuan untuk mengeksplorasi program adaptasi yang dapat dikembangkan di Taman Nasional Tanjung Puting (TPNP) berdasarkan perspektif wisatawan. Hasil penelitian menunjukkan: (1). Pasar wisata TNTP memiliki faktor ekowisata dengan kesadaran yang tinggi terhadap kepedulian lingkungan, termasuk ancaman perubahan iklim. Pengunjung TNTP memiliki etika yang tinggi terhadap alam dan budaya lokal. Umumnya, para pengunjung memiliki latar belakang pendidikan dan penghasilan yang tinggi, sangat potensial untuk melibatkan mereka dalam pelestarian lingkungan; (2). Para pengunjung di TNTP menyadari bahwa perubahan iklim merupakan tantangan serius dan memerlukan tindakan nyata. Beberapa program adaptasi yang diinginkan pengunjung adalah penggalangan dana program untuk konservasi orangutan dan habitatnya. Para pengunjung cenderung bersedia memberikan sumbangan Rp172.000/visitor. Para pengunjung mendorong manajer untuk melakukan improvisasi daninovasi teknologi terhadap perahu (kelotok), mesin yang harus efisien dan tidak berisik. Para pengunjung juga mendorong otoritas TNTP untuk membatasi jumlah pengunjung sehingga melindungi sumber daya pariwisata dan menjaga kualitas kunjungan, (3). Para pengunjung tidak mau bergabung dengan tamu lain dalam satu perahu publik dengan kapasitas lebih besar, untuk menjaga efisiensi bahan bakar dan mitigasi gas rumah kaca. Penggabungan pengunjung bepergian dengan kelompok lain, akan mengurangi kualitas perjalanan mereka di Taman Nasional Tanjung Puting. Para pengunjung juga tidak mau terlibat dalam kegiatan perkebunan di tujuan selama kunjungan mereka.

\section{Kata Kunci: \\ Perubahan iklim, ekowisata, respon terhadap adaptasi, konservasi, sumbangan, mitigasi gas rumah kaca.}

\section{PENDAHULUAN}

\section{Latar Belakang}

Pariwisata selain sebagai pihak yang terkena imbas dari perubahan iklim, juga pihak yang turut memberi kontribusi terhadap fenomena perubahan iklim. UNWTO dan UNEP (2008:33) menyatakan bahwa sektor pariwisata diperkirakan menyumbang $4,9 \%$ dari total emisi $\mathrm{CO}_{2}$ dunia. Transportasi pariwisata menyumbang emisi paling besar, sekitar $75 \%$ dari total emisi yang dihasilkan sektor pariwisata. Dalam "UNWTO's Tourism 2020 Vision" diproyeksikan perjalanan wisata internasional akan tumbuh $4,4 \%$ pertahunnya sampai tahun 2020, dan apabila bisnis pariwisata dijalankan seperti biasa (tidak ada respon adaptasi dan mitigasi emisi) maka pada tahun 2035 total emisi $\mathrm{CO}_{2}$ sektor pariwisata diperkirakan akan meningkat tajam sampai $161 \%$ lebih 
besar dari sekarang (UNWTO dan UNEP, 2008:36). Oleh karena itu UNWTO dalam Konferensi 'Climate Change and Tourism: Responding to Global Challenges' di Davos, Swiss tahun 2007 mendesak seluruh stakeholders pariwisata dunia dari level individu sampai negara untuk secara progresif melakukan langkah-langkah nyata dan mengembangkan kerangka kerja PBB pada perubahan iklim (UNFCC) guna menurunkan emisi gas rumah kaca.

Kegiatan ekowisata Taman Nasional Tanjung Puting (TNTP) yang mengandalkan atraksi orangutan tidak luput dari ancaman pemanasan global. Suhud dan Saleh (2007:3) menjelaskan bahwa perubahan iklim diduga memainkan peran penting terhadap menurunnya populasi orangutan Kalimantan, kekeringan yang luas yang terjadi di Kalimantan pada tahun 1997/1998 akibat El Nino telah menyebabkan terjadinya keba karan hutan yang besar dan telah membakar jutaan hektar hutan yang nota bene adalah habitat orangutan. Perubahan iklim juga menyebabkan perubahan pola curah hujan secara regional, sehingga akan merubah siklus hidrologi suatu wilayah yang berujung pada ketersediaan pakan alami satwa liar, termasuk Orangutan. Pada sisi lain, TNTP memiliki ekosistem gambut yang luas, sehingga memiliki peran penting dalam ekosistem global sebagai pengikat karbon bebas. Namun demikian hampir secara periodik TNTP selalu mengalami kebakaran hutan, sebanyak $50 \%$ lebih kawasan hutan TNTP adalah lahan kritis yang umumnya dikarenakan oleh aktivitas illegal logging terdahulu dan kebakaran hutan. Oleh karena itu potensi kontribusi terbaik yang dapat diberikan TNTP kepada ekosistem dunia adalah mencegah pelepasan emisi deposit karbon yang tersimpan didalamnya.

Banyak penelitian yang menunjukkan adanya tipe-tipe kelompok wisatawan yang memiliki kepedulian dan kepekaan yang tinggi terhadap isu-isu lingkungan dan budaya lokal. Tipe 'eco-tourists' memiliki potensi partisipasi yang tinggi terhadap usaha-usaha pelestarian lingkungan. Level respon dan partisipasi wisatawan akan dipengaruhi oleh berbagai stimulus baik dari dalam diri maupun luar, seperti latar belakang sosial budaya, motivasi, kepribadian dan konsep diri, kekayaan informasi, kondisi dan situasi terkini, pengalaman empirik dan lain sebagainya. Mekanisme offset emission dari emisi yang dihasilkan wisatawan dengan program konservasi (misalnya: donasi konservasi, praktek reforestasi, dll.) dapat menjadi program adaptasi yang dapat dikembangkan di TNTP. Oleh karena itu perlu dilakukan survey karakteristik wisatawan untuk untuk menakar potensi respon partisipasi wisatawan dalam programprogram adaptasi yang dapat dikembangkan sesuai dengan potensi yang dimiliki TNTP.

\section{Tujuan Penelitian}

Secara umum, tujuan yang ingin dicapai: 1). Untuk menganalisis karakteristik dan tipe wisatawan TNTP berdasarkan aspek sosiodemografi dan psikografi; 2). Untuk mengetahui dan mengkaji sikap wisatawan terhadap program- program adaptasi sebagai bentuk respon terhadap fenomena perubahan iklim; 3). Untuk mengetahui dan memberikan penjelasan program adaptasi perubahan iklim yang dapat dikembangkan di TNTP berdasarkan perspektif wisatawan.

\section{METODE PENELITIAN}

TNTP dipilih sebagai lokasi penelitian karena merupakan salah satu taman nasional model di Indonesia yang memiliki sejarah pariwisata ekologis yang cukup panjang. Penelitian dilaksanakan selama 5 (lima) bulan, mulai dari September 2010 sampai dengan Februari 2011.

Karakteristik dan tipe wisatawan didekati dari aspek demografi dan psikografi wisatawan. Aspek-aspek demografi wisatawan diketahui dengan melakukan survey terhadap variasi usia, jenis pekerjaan, tingkat pendidikan, dan asal negara. Sementara faktor psikografi wisatawan dioperasionalisasikan dari persepsi dan preferensi atraksi, motivasi berwisata, macam aktivitas, bentuk mana- 
jemen perjalanan, pilihan mode transportasi dan akomodasi, lama kunjungan serta sikapnya terhadap unsur-unsur lokal. Untuk mengetahui tipologi wisatawan, variabelvariabel yang telah ditentukan terlebih dahulu harus dilakukan skoring. Sementara guna memperoleh gambaran dibalik angka-angka yang dihasilkan maka dilakukan analisis dengan menyusunnya dalam tabel silang (cross tabulation) dan uji korelasi. Teori-teori tipologi wisatawan yang sudah ada menjadi landasan analisis sehingga didapat profil dan karakteristik wisatawan TNTP.

Sikap wisatawan terhadap fenomena ancaman perubahan iklim dipengaruhi oleh stimulus-stimulus baik dari dalam maupun luar. Stimulus yang diduga mempengaruhi sikap wisatawan dibedakan dari aspek afektif (pengalaman merasakan anomali iklim) dan kognitif (kekayaan informasi dan pengetahuan terhadap fenomena perubahan iklim). Pilihan respon adaptasi yang dipilih wisatawan dianalisis dan diuji korelasinya dengan stimulannya dengan uji korelasi chisquare dan atau Spearman.

\section{HASIL DAN PEMBAHASAN}

\section{Aspek Demografi}

Hasil survey terkait dengan perbedaan jenis kelamin wisatawan menunjukkan komposisi gender berimbang antara laki-laki dan perempuan. Hal ini menjelaskan bahwa atraksi dan aktivitas wisata di TNTP dapat dinikmati baik laki-laki maupun perempuan. Aktivitas wisata yang bersifat observatif, pengamatan satwa, tidak menuntut kekuatan fisik berlebih yang umumnya menjadi pembeda preferensi gender. Dilihat dari asal negara terlihat mayoritas wisatawan berasal dari negara-negara Eropa, Amerika dan Australia, artinya segmen pasar TNTP adalah wisatawan negara-negara 'maju' yang umumnya memiliki level pendidikan dan pendapatan yang tinggi.

Hasil dari survey terkait dengan variavel usia menunjukkan persebaran usia responden cukup merata dari berusia muda sampai tua, namun dari kecenderungan sentralnya menunjukkan kecenderungan berusia tua. Hal ini dapat dilihat dari nilai rata-rata (mean) usia responden 46,25 tahun, Median 47 tahun dan Modus 60 tahun. Cooper et.al., (1998:44), menjelaskan bahwa masa pensiun awal/dini wisatawan adalah pada umur 50-55 tahun, jika asumsi ini digunakan untuk menganalisis distribusi responden maka sebanyak $45 \%$ responden atau hampir setengah dari responden adalah wisatawan yang sudah pensiun. Hasil survey juga menegaskan bahwa pekerjaan 'pensiun' memiliki porsi terbesar dari semua pekerjaan responden, yaitu sebesar $24 \%$. Jika dikaitkan dengan klasifikasi Tujuh Generasi Dunia, maka sebagian besar responden termasuk dalam angkatan generasi "Baby Boomers", yaitu generasi kelahiran 1950-1970. National Tour Foundation dalam Gartner (1996:52) memproyeksi kan generasi 'Baby Boomers' Amerika pada tahun 2000 akan mencapai 75 juta orang dan mencapai pensiun sekitar tahun 2010an. Lebih lanjut dijelaskan bahwa sebanyak $80 \%$ lebih generasi baby boomers adalah leisure traveller dan sangat menyukai travelling ke tempat-tempat alami dan tradisional dengan kapal pesiar/ yacht serta umumnya telah mencapai kemantapan finansial. Teori ini linier dengan temuan di lapangan terkait moda transportasi yang digunakan wisatawan, bahwa $31 \%$ responden menyatakan menggunakan kapal pesiar.

Gartner (1996:16) mengemukakan bahwa segmen pasar usia matang, 'mature market', umumnya memiliki kemampuan tinggi untuk travelling. Hal ini dapat dimengerti mengingat keputusan seseorang untuk melakukan perjalanan erat kaitannya dengan kelonggaran waktu dan pendapatan. Wisatawan yang telah pensiun memiliki waktu luang yang banyak sehingga memungkinkan melakukan perjalanan ke tempat-tempat yang jauh. Dana yang diperlukan untuk mencapai ke TNTP tidak sedikit, karena wisatawan tidak jarang harus berganti-ganti pesawat.

Hasil survey terkait dengan tingkat pendidikan responden menunjukkan mayo- 
ritas responden memiliki tingkat pendidikan yang tinggi, yaitu sebesar $67 \%$ responden berpendidikan sarjana. Hvenegaard (1994) dalam Page dan Dowling (2002:93) menjelaskan bahwa ekoturis setidaknya memiliki tingkat pendidi-kan minimal Sarjana Mudabachelor. Hal senada juga dijelaskan Eagles dan Cascagnette (1995) dalam Page dan Dowling (2002:93) bahwa karakteristik ekoturis berusia lebih tua, berpendidikan lebih tinggi (post-secondary education) dan pendapatan rata-rata yang lebih tinggi dibanding dengan wisatawan biasa.

\section{Aspek Psikografi}

Faktor psikologis wisatawan dapat didekati dari derajat kesenangan/kepuasan kunjungan, preferensi atraksi, motivasi berwisata, macam aktivitas, bentuk manajemen perjalanan, pilihan mode transportasi dan akomodasi, lama kunjungan dan sikap terhadap masyarakat lokal dan sumberdaya alam. Tingkat kepuasan atas pengalaman berwisata adalah titik kulminasi dari pengalaman yang dimiliki tiap individu yang dipengaruhi oleh faktor internal dan eksternal. Hasil survey terkait dengan tingkat kepuasan wisatawan menunjukkan sebanyak $87 \%$ responden puas sampai dengan sangat puas atas perjalanan wisatanya di TNTP. Dengan kata lain dapat diterjemahkan bahwa mayoritas wisatawan memberi apresiasi yang tinggi terhadap aspek-aspek yang ditawarkan TNTP, seperti atraksi wisata, akomodasi, fasilitas, makanan, kenyamanan dan lain sebagainya.

Pariwisata TNTP menawarkan suasana alam hutan tropis beserta kehidupan satwa liarnya, khususnya Orangutan. Atraksi pariwisata TNTP dalam penelitian ini dibagi menjadi 3 (tiga), yaitu: Atraksi Orangutan di Camp Leakey, Atraksi di Pondok Tanggui dan Atraksi Susur Sungai Sekonyer. Camp Leakey pada mulanya adalah stasiun riset Orangutan, seiring dengan perubahan status kawasan hutan, areal ini selanjutnya ditetapkan sebagai zona pemanfaatan khusus TNTP, yaitu zona untuk keperluan riset dan wisata terbatas. Sejak saat itu Camp Leakey terbuka untuk pariwisata dengan atraksi utamanya adalah pemberian makan Orangutan rehabilitan, yaitu Orangutan hasil sitaan yang akan dilepasliarkan di habitat alaminya. Secara umum responden memberi appresiasi yang sangat tinggi terhadap atraksi Orangutan Camp Leakey, sebanyak 96\% responden menyatakan puas sampai dengan sangat puas atas atraksi Orangutan Camp Leakey. Salah satu yang menjadi kekuatan Camp Leakey adalah peluang perjumpaan dengan Orangutan yang cukup tinggi. Wisatawan hampir dipastikan akan dapat menjumpai Orangutan di Camp Leakey, sekalipun pada saat musim buah. Hal inilah yang menjadi perbedaan antara TNTP dengan beberapa taman nasional lainnya yang menawarkan atraksi yang sama.

Semakin tinggi persepsi wisatawan terhadap Orangutan Camp Leakey maka cenderung semakin tinggi pula derajat kepuasan kunjungannya. Orangutan adalah flagships species, yaitu selain sebagai icon pariwisata dan konservasi juga sekaligus sebagai spesies indikator kelestarian ekosistem TNTP. Orangutan memiliki profil besar, unik, lucu, cerdas dan langka sehingga mudah memberi kesan yang mendalam bagi wisatawan. Orangutan merupakan satu diantara empat spesies kera besar "Great Apes" dunia yang terancam punah dan memiliki kedekatan genetis dengan manusia. IUCN memasukkan Orangutan Borneo (Pongo Pygmaeus) sebagai spesies yang "endangered" sementara CITES memasukkannya dalam kelompok satwa Appendix I CITES (Yuwono, dkk, 2007:2). Kisah panjang perjalanan penelitian Orangutan di Camp Leakey juga menjadi cerita yang menarik bagi wisatawan. Pahit getir perjalanan penelitian Orangutan dan cerita-cerita perebutan teritori Orangutan jantan di Camp Leakey disajikan secara interaktif dan menarik di Pusat Informasi Camp Leakey sehingga memperdalam kesan terhadap Orangutan di Camp Leakey.

Pondok Tanggui adalah lokasi penelitian Orangutan lainnya selain Camp Leakey yang 
menjadi destinasi wisata. Atraksi utama yang ditawarkan di Pondok Tanggui sama dengan Camp Leakey, yaitu pemberian makanan kepada Orangutan ex-rehabilitan. Berdasarkan hasil survey wisatawan terhadap atraksi di Pondok Tanggui diketahui bahwa sebagian besar responden memberi appresiasi yang tinggi, sebesar $87 \%$ menyatakan puas sampai dengan sangat puas atas atraksi Orangutan Pondok Tanggui. Hal ini menjelaskan bahwa Orangutan Pondok Tanggui juga telah memenuhi ekspektasi kunjungan wisatawan di TNTP.

Selain Orangutan, atraksi lainnya yang ditawarkan pariwisata TNTP adalah aktivitas susur Sungai Sekonyer. Selain sebagai akses masuk menuju obyek wisata, Sungai Sekonyer ini juga sekaligus sebagai batas alam kawasan TNTP. River cruising ini menjadi salah satu aspek yang mempunyai pengaruh kuat terhadap kepuasan kunjungan wisatawan di TNTP. Mayoritas responden menyatakan appresiasi yang tinggi atas kegiatan susur sungai ini. Hal ini dapat dipahami karena sepanjang perjalanan wisatawan akan mendapat banyak pengalaman yang jauh berbeda dari kesehariannya, baik fasilitas, makanan maupun sensasi pengalaman yang didapatkan. Kekayaan flora dan fauna sempadan sungai memanjakan mata wisatawan yang menggemari atraksi alam, khususnya satwa liar. Sejak masuk muara Sekonyer wisatawan sudah disuguhi atraksi gerombolan primata di tajuk pohon, seperti Bekantan, Kera Ekor Panjang, Beruk, Lutung, bahkan tidak jarang Orangutan liar juga sering kelihatan di sepanjang Sungai Sekonyer. Tidak mengherankan jika responden yang menyatakan puas terhadap perjalanan wisatanya di TNTP cenderung memiliki persepsi yang tinggi terhadap aktivitas susur sungai.

Aspek perjalanan susur sungai lainnya adalah makanan. Persepsi wisatawan terhadap makanan yang disajikan menunjukkan sebanyak $96 \%$ responden menyatakan puas sampai sangat puas. Makanan yang disajikan awak kelotok kepada wisatawan pada umumnya adalah masakan Indonesia, seperti nasi goreng, singkong rebus, pisang goreng, mendoan, dll. Disimpulkan bahwa responden memiliki tingkat adaptasi yang baik terhadap makanan lokal.

Fasilitas jalan menuju lokasi pemberian makan (feeding station) Orangutan adalah jalan setapak alami yang tidak ada sentuhan semen sama sekali. Jalan ini pada saat hujan cukup licin dan seringkali banyak pacet yang menempel di betis wisatawan. Namun demikian hasil survey justru menunjukkan mayoritas responden (72\%) relatif puas dengan fasilitas yang ada. Hal ini menegaskan bahwa motivasi wisatawan bukanlah untuk mencari kemudahan dan kenyamanan melainkan lebih pada pencarian pengalaman baru yang menantang. Sementara dari aspek manajemen perjalanan wisata, mayoritas wisatawan cenderung menggunakan jasa operator lokal. Manajemen perjalanan yang dimaksud disini adalah model pengaturan segala keperluan selama perjalanan wisata, baik tiket hotel, taxi, makan, sewa jasa pemandu, sewa kelotok dan lain sebagainya. Ada 3 (tiga) bentuk manajemen perjalanan yang dilakukan, yaitu membeli paket perjalanan dari operator internasional (all in package), membeli paket perjalanan operator lokal (on site package) dan perjalanan mandiri tanpa bantuan tour operator. Survey menunjukkan $20 \%$ responden menggunakan jasa operator internasional, 64\% responden menggunakan jasa operator lokal dan 16\% responden berangkat sendiri tanpa menggunakan jasa operator.

Jika dilihat dari jumlah atau besar rombongan, wisatawan ke TNTP secara umum cenderung melakukan perjalanan secara berkelompok kecil sampai sedang. Besar kecilnya kelompok-kelompok wisatawan ini diduga ada hubungannya dengan variasi umur wisatawan. Dari hasil tabulasi silang antara jumlah rombongan dan variasi usia terlihat kecenderungan responden usia muda (30-39 tahun) lebih suka melakukan perjalanan wisata berdua atau berpasangan, sementara pada usia sedang sampai tua (40 
tahun keatas) terlihat cenderung menyukai perjalanan dalam kelompok 3 sampai dengan 5 orang. Hal ini dapat dipahami karena pada usia muda seseorang akan lebih senang melakukan perjalanan dengan pasangannya masing-masing, seiring dengan bertambahnya usia maka jumlah anggota keluarga bertambah dan besar rombongan juga semakin besar. Dalam akhir masa pensiun, ketika kemampuan fisik dan finansial makin melemah bahkan seringkali kehilangan pasangannya, mendorong individu-individu tersebut untuk bergabung dengan kelompok kecil lain untuk melakukan perjalanan yang cenderung bersifat hotel-based (Cooper, 1998: 44). Dari hasil uji korelasi memperlihatkan bahwa semakin tua umur responden cenderung akan melakukan travelling dalam kelompok yang lebih besar. Mereka tidak lagi melakukan perjalanan berpasang-pasangan melainkan bergabung dalam kelompokkelompok kecil sampai dengan sepuluh orang.

Sementara hasil survey terkait dengan pilihan penginapan menunjukkan $75 \%$ responden memilih menginap di atas kelotok, $16 \%$ di Hotel Rimbalodge (AC) dan 6\% responden memilih kombinasi antara Hotel Rimbalodge (AC) Kelotok dan 3\% tidak menginap. Pengalaman yang didapatkan wisatawan dengan menginap di atas kelotok di tengah belantara hutan tropis lebih menarik. Hasil tersebut menegaskan bahwa wisatawan TNTP baik yang berusia tua maupun muda bukan tipe wisatawan yang 'manja' yang tergantung dengan fasilitas hotel yang lengkap dan mewah.

Dalam konteks kepekaan terhadap masyarakat lokal, mayoritas wisatawan (88\%) memandang penting keterlibatan masyarakat dalam kegiatan pariwisata TNTP. Dalam prakteknya wisatawan juga telah banyak melibatkan masyarakat dalam manajemen perjalanan wisatanya seperti pemandu wisata, tukang masak, awak kelotok dan lain sebagainya. Sementara kepekaan wisatawan terhadap isu lingkungan didekati dari persepsinya atas fenomena perubahan iklim, dimana sebanyak $79 \%$ responden menyatakan perubahan iklim merupakan permasalahan lingkungan yang serius sampai sangat serius yang perlu segera direspon. Pengalaman empiris merasakan dampak pemanasan global diduga mempengaruhi persepsi wisatawan terhadap permasalahan perubahan iklim tersebut. Hasil uji statistik antara pengalaman empiris dengan persepsi perubahan iklim menunjukkan adanya hubungan dimana wisatawan yang pernah merasakan anomali iklim cenderung memiliki persepsi perubahan iklim adalah masalah penting yang harus direspon dengan serius. Sebagian besar responden juga menyadari bahwa mereka turut berkontribusi terhadap pemanasan global melalui emisi yang dikeluarkan dari pesawat yang membawa mereka ke TNTP. Informasi mengenai maraknya konversi hutan menjadi kebun sawit, illegal logging dan kebakaran hutan yang kerap menghiasi media massa menjadi catatan tersendiri wisatawan. Sebagian besar responden juga menyatakan dukungan terhadap kegiatan rehabilitasi hutan guna meredam laju pemanasan global. Hal-hal tersebut menjelaskan bahwa wisatawan TNTP memiliki kepedulian terhadap masyarakat lokal dan memiliki kemampuan analitik tinggi dalam menginterpretasi isu-isu lingkungan.

\section{Sintesa Aspek Demografi dan Psikografi}

Karakteristik demografi dan psikografi responden yang telah dijelaskan diatas memiliki kemiripan dengan ciri-ciri wisatawan tipe Ekoturis. Aspek yang paling menonjol adalah preferensi terhadap atraksi alam, tingkat adaptasi yang baik serta sensitivitas yang tinggi terhadap alam dan masyarakat sekitar. Apabila didekati dengan teori Psikografik Plog (1977) maka wisatawan TNTP cenderung ke arah spektrum Near Allocentric sampai Allocentric. Hal ini didasari dari tingginya keterlibatan masyarakat lokal dalam perjalanan wisata, preferensi atraksi dan aktivitas wisata yang lebih menyatu 
dengan alam, adaptasi yang tinggi terhadap makanan lokal, adaptasi yang baik terhadap fasilitas dan akomodasi lokal, tipe manajemen perjalanan yang cenderung mandiri serta pengetahuan dan sensitivitas yang tinggi terhadap isu-isu lingkungan. Tingkat pendidikan dan pendapatan yang relatif tinggi juga menjadi features yang umumnya melekat pada wisatawan tipe ekoturis.

Motivasi perjalanan wisatawan umumnya adalah untuk memperkaya pengetahuan (khususnya tentang Orangutan) dan pengalaman berwisata di alam terbuka. Hasil temuan karaketristik demografis dan psikografis wisatawan menjelaskan bahwa pasar wisata TNTP memiliki pengetahuan dan kepedulian yang tinggi terhadap lingkungan. Artinya wisatawan TNTP memiliki potensi yang besar untuk terlibat dan berpartisipasi dalam program program adaptasi yang melibatkan wisatawan.

\section{Donasi Konservasi Orangutan}

Program “Donasi Konservasi Orangutan" adalah program offset emission dari emisi yang telah dihasilkan dengan donasi atau penyediaan dana untuk konservasi $\mathrm{O}$ rangutan dan habitatnya. Dengan melakukan pelestarian habitat Orangutan (ekosistem hutan gambut) sama artinya dengan telah melakukan upaya penambatan cadangan karbon dunia. Program Donasi Konservasi Orangutan ini mendapat respon yang baik dari responden (42\%), meskipun persentase responden yang masih ragu-ragu juga cukup tinggi. Keraguan responden lebih dikarenakan faktor penawaran, yaitu kurang jelasnya konsep program yang ditawarkan seperti mekanisme penggunaan dananya, uraian program, mekanisme pelaporan dan akuntabilitas dan lainya. Oleh karena itu agar program donasi Orangutan ini mendapatkan respon partisipasi yang lebih baik dari wisatawan, maka harus disusun detail program yang jelas seperti bentuk pelaksanaan kegiatan, ukuran keberhasilan, sistem monitoring evaluasi kegiatan dan aspek-aspek lainnya.
Image Orangutan sebagai flagship species lebih mudah menarik simpati wisatawan. Profil dan status Orangutan (Pongo pygmaeus) yang "endangered" IUCN menjadi motivator bagi wisatawan dalam memutuskan sikap untuk memberi donasi. Hal ini sejalan dengan hasil penelitian Bart (1972) dalam Shackley (1996:19) bahwa image satwa yang terancam punah (endangered species) mampu mempengaruhi dengan kuat perasaan seseorang. Pariwisata berbasis flagships species berpeluang besar sebagai instrumen penggalang dana konservasi (Wallpole dan Williams, 2002:544). Nilai rata-rata donasi yang bersedia disumbangkan wisatawan adalah Rp. 172.000.00 per orang. Apabila kita buat asumsi sederhana sebanyak $42 \%$ (besar responden yang bersedia memberi donasi) wisatawan mancanegara pada tahun 2009 (2.274 wisatawan), maka dana konservasi Orangutan yang dapat dikumpulkan adalah Rp164.273.760 setahun. Asumsi ini menggambarkan jika program ini dibuat dan dikelola dengan baik dapat menghasilkan dana yang cukup untuk membantu upaya kelestarian hutan TNTP.

\section{Donasi dengan Konsep Pohon Adopsi}

Bentuk program adaptasi lainnya adalah penggalangan dana dengan konsep 'pohon adopsi'. Program ini adalah model kerjasama rehabilitasi hutan melalui mekanisme penanaman dengan melibatkan wisatawan sebagai penyandang dana dan Balai TNTP sebagai pelaksana dan penanggung jawab. Konsep pohon adopsi ini mendapat partisipasi yang relatif lebih kecil jika dibandingkan dengan program donasi konservasi Orangutan. Hasil survey menunjukkan 25\% responden menjawab tidak bersedia sampai sangat tidak bersedia, 23\% menjawab bersedia sampai sangat bersedia dan $52 \%$ responden memilih jawaban netral. Komposisi jawaban responden yang dengan tegas bersedia berpartisipasi terlihat kecil, yaitu 23\%. Presentase responden yang dengan tegas tidak bersedia membeli pohon adopsi 
memperlihatkan porsi yang hampir sama besarnya dengan responden yang bersedia membeli pohon adopsi sehingga cukup sulit diinterpretasi kecenderungannya. Berdasarkan perspektif konsumen maka program donasi konservasi Orangutan punya potensi implementasi lebih besar dibanding dengan konsep pohon adopsi. Konsep penggalangan dana dengan menggunakan simbol satwa (Flagship species) jauh lebih efektif jika dibandingkan dengan simbol pohon.

\section{Praktek Reforestasi}

Konsep reforestasi adalah program adaptasi penambatan karbon yang melibatkan wisatawan melalui kegiatan penanaman dalam plot atau area kritis yang telah ditentukan. Selain sebagai bentuk kongkret usaha konservasi, program penanaman hutan yang melibatkan wisatawan juga diharapkan dapat menambah pengalaman selama kunjungan di TNTP.

Hasil survey terhadap kebersediaan wisatawan terlibat dalam kegiatan reforestasi selama di TNTP terlihat $12 \%$ responden menjawab sangat tidak bersedia, 9\% responden menjawab tidak bersedia, $61 \%$ responden memilih netral, $14 \%$ responden menjawab bersedia dan $4 \%$ menyatakan sangat bersedia. Distribusi frekuensi ini menunjukkan mayoritas responden raguragu untuk berpartisipasi dalam program ini. Jika dilihat dari presentase responden yang telah menentukan sikap dengan tegas baik bersedia maupun menolak memperlihatkan porsi yang hampir sama besar, sehingga cukup sulit untuk memprediksi variabel apa yang menyebabkan tingginya jawaban netral responden tersebut. Sikap responden ini berbeda dengan persepsinya tentang perlunya usaha reforestasi hutan, dimana sebanyak $85 \%$ responden menyatakan setuju sampai sangat setuju perlu dilakukan usaha reforestasi lahan kritis dalam meredam laju pemanasan global. Hal ini menjelaskan bahwa pada tataran kognitif mayoritas responden memiliki pengetahuan dan kesadaran yang tinggi atas perlunya upaya reforestasi, namun pada level konasi (sikap) responden cenderung netral atau pasif. Responden sadar salah satu upaya dalam membantu meredam laju pemanasan global adalah dengan melakukan reforestasi, namun usaha ini tidak bisa dibebankan kepada wisatawan karena memang tujuan kedatangannya adalah untuk berwisata. Meskipun memiliki sensitivitas dan kepedulian yang tinggi terhadap isu-isu lingkungan, akan tetapi tujuan utama mereka ke TNTP bukan sebagai relawan atau voluenteer konservasi melainkan untuk mencari pengalaman wisata dan suasana berbeda yang menyegarkan (refreshing).

\section{Penggunaan Transportasi Umum (Kelotok)}

Konsep penyediaan kelotok sebagai bentuk mitigasi gas rumah kaca melalui strategi efisiensi penggunaan energi tak terbarukan. Gagasan penggabungan wisatawan dalam satu kelotok besar ini didasari fakta bahwa wisatawan datang dalam kelompok-kelompok kecil dan menyewa satu kelotok yang daya tampungnya jauh lebih banyak. Dengan menyediakan kelotok umum dengan kapasitas yang besar maka rombongan wisatawan dapat diangkut sekaligus, sehingga efisien dalam konsumsi BBM dan sekaligus meminimalisasi emisi gas buang.

Menggunakan transportasi publik memerlukan kesadaran tinggi untuk berbagi tempat dan privasi dengan orang lain, sehingga memerlukan stimulan-stimulan yang kuat. Dari survey terhadap kebersediaan responden bergabung dalam kelotok umum terlihat sebanyak $29 \%$ responden menyatakan sangat tidak bersedia, 36\% responden tidak bersedia, $25 \%$ responden memilih netral, $10 \%$ responden menyatakan bersedia dan tidak ada satupun responden yang menjawab sangat bersedia menggunakan kelotok umum. Hasil ini dapat dipahami karena moda transportasi kelotok yang digunakan juga sekaligus sebagai atraksi wisata itu sendiri. Aktivitas menyusuri 
belantara hutan tropis TNTP dengan kelotok menjadi salah satu kekuatan pariwisata TNTP. Sepanjang perjalanan wisatawan dapat dengan mudah menyaksikan orangutan liar dan satwa liar lainnya di sepanjang Sungai Sekonyer.

\section{Implementasi Teknologi Ramah Lingkungan}

Hasil survey menunjukkan mayoritas wisatawan menilai emisi yang dikeluarkan kelotok belum berbahaya. Namun demikian wisatawan memberi catatatan khusus pada kebisingan yang ditimbulkan dari mesin kelotok. Umumnya mesin kelotok adalah mesin diesel tua yang menghasilkan suara yang cukup nyaring, sehingga cukup memekakkan telinga wisatawan yang notabene hampir sepanjang hari berada diatas kelotok. Sebagian besar kelotok wisata juga tidak dilengkapi peredam di ruang mesin sehingga suara deru mesin sangat kuat terdengar di geladak kelotok.

Wisatawan menghendaki adanya regenerasi mesin kelotok dengan mesin teknologi terbaru yang relatif lebih hemat bahan bakar dan halus suaranya. Penggunaan bahan bakar biofuel atau tenaga surya dapat menjadi solusi yang ramah terhadap lingkungan. Pihak pengelola juga perlu melakukan pengaturan dan standarisasi kelotok, baik pada kelengkapan fasilitas penunjang, safety equipment dan peredam mesin. Dengan demikian kepuasan dan pengalaman berwisata tetap terjaga dan sekaligus juga sebagai bentuk kongkret pelaksanaan praktek pengusahaan pariwisata yang ramah lingkungan.

\section{Pengaturan/Pembatasan Kunjungan}

Survey terhadap tingkat kebisingan/ kesesakan di feeding station pada saat Orangutan's feeding time menunjukkan tingkat kebisingan yang relatif tidak menganggu, yaitu 73\% responden menyatakan relatif nyaman. Secara umum kepadatan dan kesesakan yang ditimbulkan oleh wisatawan di feeding station masih dalam rentang toleransi wisatawan. Meskipun relatif belum mengganggu, namun sebagian besar responden $(70 \%)$ menyatakan perlu pembatasan kunjungan wisatawan guna menghindari kemungkinan ledakan pengunjung. Hal ini dapat dipahami karena ruang yang disediakan untuk menyaksikan Orangutan di feeding station cukup terbatas, sementara waktu atraksi kurang lebih hanya dua jam sehingga semua wisatawan akan terkonsentrasi di feeding station. Hal ini berpotensi menimbulkan kesesakan dan kerusakan pada anakan tumbuhan di sekitar feeding station oleh injakan kaki wisatawan.

Berdasarkan survey tentang luas ruang yang nyaman bagi wisatawan dalam menikati atraksi orangutan dengan tanpa terganggu oleh wisatawan lainnya adalah seluas $3,01 \mathrm{~m}^{2} /$ orang (daya dukung psikologis). Dengan luas ruang yang tersedia untuk wisatawan $\pm 56 \mathrm{~m}^{2}$ dan dengan daya dukung psikologis $3,01 \mathrm{~m}^{2}$ maka dapat diketahui daya dukung Fisik (PCC) feeding station adalah 19 orang/hari, atau 6.840 orang/tahun. Angka ini masih diatas jumlah kunjungan wisatawan factual pada tahun 2009, sehingga belum melampaui daya dukung fisik dan psikologis wisatawan.

Jika dilihat dari daya dukung ekologisnya maka luas feeding station yang ideal untuk menampung wisatawan sebanyak 3.786 orang (tahun 2009) adalah seluas $63 \mathrm{~m}^{2}$. Artinya dengan luasan yang ada saat ini (56 $\left.\mathrm{m}^{2}\right)$ maka secara ekologis feeding station Camp Leakey terlalu kecil atau sempit. Oleh karena itu untuk mengakomodir kenaikan kunjungan dan menghindari kerusakan di feeding station, maka luas feeding station yang dibuat harus memperhatikan proyeksi pencapaian kunjungan wisatawan. Jika proyeksi target wisatawan per tahun adalah 4.000 wisatawan maka luas feeding station yang ideal adalah $67,3 \mathrm{~m}^{2}$, sedangkan untuk target 10.000 wisatawan setahun maka luas feeding stationnya $168,3 \mathrm{~m}^{2}$. Dengan memperhatikan daya dukung ekologis maka pencapaian target ekonomi dari jumlah kunjungan dapat ditingkatkan dan disisi lain potensi kerusakan anakan pohon juga dapat dihindari. 


\section{KESIMPULAN}

Wisatawan TNTP adalah tipe ecotourist yang memiliki sensitivitas dan kepedulian tinggi terhadap unsur-unsur lokal. Mereka memiliki pemahaman yang baik terhadap fenomena pemanasan global, baik penyebab maupun dampaknya. Wisatawan memandang perubahan iklim sebagai fenomena serius dan perlu direspon dengan langkah kongkret.

Program-program mitigasi gas rumah kaca yang melibatkan wisatawan secara langsung seperti penanaman pohon/ reforestasi dan penghematan energi melalui penggabungan rombongan dalam kelotok umum kurang direspon oleh wisatawan. Penggabungan rombongan dalam kelotok justru dapat mengurangi kualitas pengalaman dan kepuasan kunjungan.

Sementara respon adaptasi yang dapat dikembangkan menurut perspektif wisatawan adalah: 1). Fund raising menggunakan flagship species (Orangutan). Wisatawan bersedia memberi donasi sebesar Rp 172.000 per orang; 2). Regenerasi mesin kelotok dengan teknologi yang lebih efisien dalam penggunaan energi. Penggunaan bahan bakar biofuel atau solar cell pada kelotok wisata juga menjadi alternatif solusi yang ditawarkan wisatawan; 3). Secara ekologis jumlah kunjungan wisatawan telah melampaui daya dukung ekologis (ECC) sehingga perlu adanya pembatasan wisatawan untuk menghindari kerusakan lebih lanjut.

\section{DAFTAR PUSTAKA}

Anonim, 2006, Laporan Kebakaran Hutan Taman Nasional Tanjung Putting, OFI, Pangkalan Bun.

Anonim,2008, Pedoman Pengelolaan Pengunjung di Kawasan Hutan, Direktorat Pemanfaatan Jasa Lingkungan dan
Wisata Alam, Dirjen PHKA, Departemen Kehutanan, Jakarta.

Atkinson, R.J., dan Hilgard, E.R., 1991, Pengantar Psikologi, Erlangga, Jakarta.

Cooper, Fletcher, Gilbert, Sheperd, and Wanhill, 1998, Tourism Priciple and Practice, Prentice Hall, London.

Eagles,P.F.J., McCool, S.F., 2002, Tourism in National Parks and Protected Areas: Planning and Management, Cabi Publishing, London.

Edgell, D.L.(ed), 2006, Managing Sustainable Tourism: A Legacy For The Future. Haworth Hospitality Press, Birmingham, UK.

Fennel, D.A., 2002, Ecotourism and Programme Planning, CABI Publishing, New York.

Fennel, D.A., 2006, Tourism Ethic, Channel View Publication.

Gartner, W.C., 1996, Tourism Development: Principles. Process and Policies, Van Nostrand Reinhold, New York.

Hall, C.M., and Page, S.J., 2002, The Geography of Tourism and Recretation: Environment. Place and Space, Routledge, New York.

Higham,J.(ed).,2008, Critical Issues in Ecotourism: Understanding a Complex Phenomeno, Butterwort - Heinemann, UK.

Masson,P., 2008, Tourism, Impacts, Planning and Management, ButterwortHeineman, UK.

Mill, R.C., dan Morrison, A.M, 1992, Tourism System: An Introductory Text, $2^{\circ}$ ed., Prentice-Hall, New Jersey

Nantha, H.S., and Tisdel, E.C., 2009, The orangutan-oil palm conflict: economic constraints and opportunities for conser- 
vation, Biodiversity Conservation (18), 487-502.

Shakley, M., 1996, Wildlife Tourism, Thompson International Business Press.

Sing, T., 2004, New Horizons in Tourism: Strange Experiences and Stranger Practices, CABI, New York.

Suhud, M., dan Saleh, C., 2007, Dampak Perubahan Iklim Terhadap Habitat Orangutan, WWF-Indonesia, Jakarta, Indonesia.

Susilo, H.J., 1997, The Tanjung Putting National park and Biosphere Reserve.
UNWTO, dan UNEP, 2008, Climate Change and Tourism; Responding to Global Challenge, Madrid.

Wallpole, J.M., and Williams, N.L., 2002, Tourism and Flagships Species in Conservation, Biodiversity and Conservation (11), 543-547.

Yuwono,E.B.,Susanto,P., Saleh, C., Andayani, N., Prasetyo, D., dan Atmoko, S.C.U., 2007, Petunjuk Teknis Penanganan Konflik Manusia-Orangutan di Dalam dan Sekitar Perkebunan Kelapa Sawit, WWF Indonesia. 